\title{
The Role of ICT on SMEs' Performance
}

\author{
Mariska $^{1}$ \\ Ministry of National Development Planning/BAPPENAS RI
}

\begin{abstract}
Small and medium enterprises (SMEs) have an important role in economic growth and development in various countries. In line with the increasingly open global economy, SMEs are beginning to expand their market to the international scale, and compete competitively with other SMEs as well as big businesses. This is only possible if SMEs adopt and utilize information, communication, and technology (ICT) and various applications such as e-commerce and e-business. This paper describes a literature study on the role of ICT on the performance of SMEs and constraints in the adoption of ICT which has the potential to inhibit the optimization of ICT utilization by SMEs. As well as, describe the benefits that SMEs have through ICT applications and some inputs as recommendations for the solution of the above problems.
\end{abstract}

Keywords: SME, ICT, e-commerce 


\title{
The Role of ICT on SMEs' Performance
}

\author{
Mariska, BAPPENAS
}

\section{Introduction}

Small and Medium Enterprises (SMEs) ${ }^{2}$ have been the back bone of economy in many nations as they create job opportunities and significantly contribute to gross domestic products (GDP). Ayyagari, Beck, and Kunt (2007) found that formal SMEs provide 60 percent employment opportunities in manufacturing sector and contribute not less than 50 percent of GDP on average in high-income countries. SMEs has also critical role to alleviate poverty and improve economy development in low-income countries. According to Beck, Kunt, and Levine (2005) the World Bank settle affirmative policy to assist SMEs' development based on three arguments, i.e. SMEs heighten market competitiveness and entrepreneurship which add positive impact to economy, create innovation, and engage with cumulative productivity growth. Ardic, Mylenco, and Saltane (2011) also argue that SMEs are generally more innovative and responsive than large scale enterprises since they deal with niche market.

Open market economy and globalization provide opportunities for SMEs to widen their potential market share, as well as cause the market become more competitive. Information, communication, and technology (ICT) utilization become one of the key factors to determine SMEs performance in global competition. ICT and its various applications deliver numerous advantages to SMEs in terms of external and internal supporting business process (OECD, 2004). SMEs are able to access diverse information from internet to support their business and adopt ICT applications to improve their management system.

This paper provides literature study regarding ICT and its applications usage on SMEs' business process such as electronic commerce (e-commerce), and electronic business (e-business); analysis the role of ICT on SMEs' performance; and breakdown barrier factors as well as potential solution for maximizing the usage and benefit of ICT on SMEs.

\section{Impact of ICT Adoption on SMEs' Performance}

\subsection{SME Performance}

ICT and its application provide many benefit for ample spectrum of SMEs business process. In internal organization aspect, ICT and its application can support SMEs' management systems in terms of easiness in correspondence and transfer of information within the internal organization that result to management effectiveness. At the same time, internet through world wide web (website) as a part of ICT, supply information for SMEs to explore their market share and connect directly to Business-to-Business (B2B) and Business-to-Consumer (B2C) sectors.

ICT is utilized both as an input production of SMEs and in transaction process when selling the product or services. In production process, ICT intensify SMEs performance through indirect cost saving. ICT can reduce labor cost but at the same time increase their productivity, and lower related input cost such as information cost (Chowdhury \& Wolf, 2003). On the sort run, using ICT in business process can encourage input and output market enlargement. The implementation of ICT on the long run will bring more benefit as it overhauls SMEs business process including their production process and transaction methods.

\subsection{Market Expansion}

Through the internet, SMEs can explore and expand their potential market share. For example, e-commerce utilization allows SMEs to penetrate their business directly to specific market (niche), also increase their opportunities to sell more as the result of open information and reducing cost of information and transaction. ICTs, especially e-commerce and e-business, can be an excellent way to unite sellers and buyers, and facilitating a better communication between them. As a result, ICTs can improve dealing process between sellers and buyers, and open the opportunities for SMEs to expand global market. Hence, SMEs will not always rely on local market instead of develop their international market.

2. Although there is no standard definition on Small and medium-sized enterprises (SMEs), in this paper we use SMEs definition from OECD which define SMEs as firms with fewer than 250 employees. 


\section{ICT and Its Application Adoption on SMEs Business Process: Barriers and Potential Solution}

Despite the potential benefit offered by ICT utilization, SMEs still face barriers that prevent them to optimize the advantages from using ICT. Cragg and King (1993) identified that financial and managerial resource inadequacy, and technical incompetence are the major barriers (as cited in Kartiwi \& MacGregor, 2007). To engage with ICT means requires SMEs to make investment not only in financial aspect, but also in ICT users' skill. According to OECD survey, the use of ICT by SMEs is increasing year by year (OECD, 2004). However, large-sized enterprises are faster to adopt ICT compare to SMEs, particularly in developing countries (Kartiwi \& MacGregor, 2007).

Electronic commerce (e-commerce) and electronic business (e-business) as part of ICT innovation are considered as the most important supporting system for business process. Large-sized enterprises have been implemented e-commerce and e-business long time before SMEs even aware of it.

\subsection{Electronic Commerce (e-commerce)}

The terme-commerce has no universally definition. According to Investopedia, e-commerce refers to "a type of business model, or segment of larger business model, that enables a firm or individual to conduct business over an electronic network, typically internet." Similarly, Daniel, Wilson, and Myers (2002) define e-commerce as ICT utilization in business-to-business (B2B) and business-to-consumer (B2C) activities in terms of online transaction that involve selling goods or services (as cited in Mazzarol, 2015). ${ }^{3}$

To describe and illustrate the scope of e-commerce, Jahanshashi, Gasthi, Khaksar, and Pitamber (2011) group it into five different application, i.e. electronic advertising, which provide online information related to product, company, buying procedure to customers; electronic customer support office which provide interactive customer supporting such as frequently asked question (FAQ), feedback and queries, online application, and personalized email communication; electronic marketing which facilitate customer to communicate directly to sales agent, allow the firm to get information about customers preference, and achieve customer satisfaction; electronic payment system including electronic fund transfer (EFT), online credit card processing, e-money, prepaid card, and; electronic order and delivery including firmsupplier relation support, online order, lower cost transaction, tracking goods delivery, and electronic data interchange (EDI).

The using of e-commerce is growing, yet contribute relatively small amount of economic gain of all over firms' activities including large-sized enterprises. In 2000, total on-line sale was only 10 percent or less of total sales transaction (OECD, 2004). This shows that the adoption and utilization of e-commerce has relatively low percentage. Parasuraman (2000) found that different gender and range of age are significantly influence keenness to adopt technology (as cited in Mazzarol, 2015). E-commerce adoption also depend on firms' owner and/or manager education background and income. The higher income that she/he receives, the more optimist and open toward technology.

OECD (2004) claim that unsuitable e-commerce to SMEs type of business as a major factor causing SMEs reluctant to adopt e-commerce in their business process, for example SMEs in construction sector and transportation service. In addition, SMEs usually have only few technology-skilled workers who are able to understand and utilize e-commerce. Even though SMEs become more aware of the potential benefit generated from adopting e-commerce, they still employ unskilled workers and have no time to learn more about ICT and e-commerce. Another reasons which influence SMEs not to implement e-commerce are pessimistic feeling on e-commerce payoff, dubious about customers' access to e-commerce, and insecure about technology and fraud on on-line transaction.

\subsection{Electronic Business (e-business)}

Similar with e-commerce, the term e-business has no standard definition. Consequently, Lawson et al. (2003) argue that e-business is often misleading and/or use it interchangeably (Fillis et al., 2003) with the term e-commerce and other related term (as cited in Pavic, Koh, Simpson, \& Padmore, 2007). Mazzarol (2015) refers e-business as part of ICT that use in 
business process to enlarge its production, consumer relation, and internal management. While IBM has its own definition on e-business as cited in Pavic et al. (2007, p. 322), "A secure, flexible and integrated approach to delivering differentiated business value by combining the systems and processes that run core business operations with simplicity and reach made possible by internet technology."

E-business is often more likely the next stage of e-commerce, since e-business is more complex and involving "business process reengineering" (OECD, 2004, p. 19) and more sophisticated technology. In other words, e-commerce implementation that deal with B2B and B2C is part of e-business plan of action. Pavic et al. (2007) state that e-business is "a powerful vehicle" that create advancement within a firm (p. 322). The concept of e-business is beyond of technology. E-business utilization aims not only to escalate business performance, but also to meet customers need. E-business provide interconnection and interaction system within the internal organization (Pavic et al., 2007). Rodgers et al. (2002) assert that there is no longer hindrance for all business actors including service providers, suppliers, and customers to communicate each other; therefore, this bring positive impact to loyalty increasing and firm's profitability as well as competitive advantage (as cited in Pavic et al., 2007).

Some research finding suggest that internet utilization among SMEs is still in embryonic stage which shows that the usage of internet is limited only to send email, document transfer and information collection. According to Supri et al. (2000), success in adopting and implementing ICT rely on some factors including the size of organization, structure, human resources inside the organization, and financial resources and capability (as cited in Pavic et al. 2007). As an illustration, SMEs would not adopt e-business system if benefit gained from adopting it is less than or equal to the cost of adopting and maintaining the system. Similar with e-commerce, the organization also lack of human capital that know how to utilize e-business. Although SMEs are aware that implement e-business will give many benefit such as reducing transaction cost, responding to competitors, improving business competitiveness, and increasing sales.

\subsection{Potential Solution}

Some study provide recommendation to overcome the obstacle regarding e-commerce adoption on SMEs. The result suggest that government support is needed to assist SMEs adopting ICT. The most important thing is to provide ICT infrastructure that can be accessed by SMEs at affordable cost. This policy will give incentive for SMEs to use ICT. Governments are also expected to set policies and approach toward the promotion of e-commerce adoption by SMEs. This include coaching and education program to introduce e-commerce and help SMEs to defeat their insecurity and discomfort feeling about this technology. Another action needed is to establish policy framework as a guidance to adopt e-commerce to become more competitive. Government also need to improve on-line transaction for both sellers and buyers and prevent potential fraud, ensure that buyers can use their account payment safely and received their orders and the buyers also feel safe from irresponsible buyers.

Helping SMEs adopt e-business in their business process can be done through developing SMEs owners and/or managers awareness and knowledge of ICT and e-business benefit and how important it is to improve business effectiveness and profitability. Some study also suggest that the computing service providers are preferred to build the easiest and convenient but at the same time offer highly reliability e-business system for SMEs (Mazzarol, 2015). Jones et al. (2014) also emphasize the important of owners and/or managers point of view towards ICT and e-business payoff (as cited in Mazzarol, 2015). Since micro-sized enterprises tend to look for short term payoff, government's role is needed to overcome this problem. Any programs offered by the government should deliver instance benefit to SMEs who adopt the technology. However, the most important thing is to provide assistance, education, and support service for the implementation of ICT and e-business. This is critical because SMEs tend to be more ignorant toward government's assistance when it come without training, consultation, and evaluating section.

\section{Conclusion}

The usage of ICT in SMEs business process is no longer a new phenomenon. Although not all SMEs have implemented ICT, the number of business using ICT is growing all the time, particularly e-commerce and e-business. The finding of the study is that ICT has significant 
role to improve SMEs performance and market expansion. The utilization of ICT especially e-commerce and e-business make business process more effective and efficient. Using these tools help SMEs to reduce their overall cost including production cost and transaction cost. ICT also help SMEs to expand their potential market; therefore they should not rely only on local market, but insert the penetration on international market in their business goals.

Two derivations of ICT that are used the most in business process are e-commerce and e-business. E-commerce provide opportunities for the SMEs to sell their products or service directly to consumer (B2C), and allow them to have business transaction between other suppliers or sellers (B2B). E-commerce might be the basic one of ICT that is easy to use and accessed by the SMEs. However, because of some barriers regarding technical skilled in terms of technology, psychology condition of business owners and/or managers who feels unsecure and uncomfortable about digital technology, and lack of internet infrastructure support, the utilization of ICT is not already optimal.

E-business might be more complex to use than e-commerce, but the utilization of e-business can cover most of the business task especially related to internal organization management. Using e-business means that all component of SMEs has to be ready to engage with it because the system will take significant part in business process both in managerial level and lower level. Unfortunately, the usage of e-business is still far behind the expectation. The determinant of this problems is more likely on owners and/or managers' perception about e-business adoption. They are aware of the benefit of using e-business yet still reluctant to use it because of human resource and financial issues.

Fundamentally, government play important role in providing potential solution to defeat the barriers of ICT adoption among SMEs.Government need to create incentive for SMEs to increase their interest adopting ICT. In addition, government intervention on policy making toward the ICT adoption is needed as the guidance for SMEs. Government also should provide technology system that can benefit the adopters in short run and facilitate training and education program to use ICT. 
References

Afshar Jahanshahi, A., Ali Hajizadeh Gashti, M., Mohammad Sadeq Khaksar, S., \& Kachardas Pitamber, B. (2011). Electronic commerce applications among Indian small and medium enterprises. Information Management and Business Review, 22(6), 276-286.

Ayyagari, M., Beck, T., \& Demirguc-Kunt, A. (2007). Small and medium enterprises across the globe. Small Business Economics, 29(4), 415-434.

Beck, T., Demirguc-Kunt, A., \& Levine, R. (2005). SMEs, growth, and poverty: cross-country evidence. Journal of economic growth, 10(3), 199-229.

Chowdhury, S. K., \& Wolf, S. (2003). Use of ICTs and the economic performance of SMEs in East Africa (No. 2003/06). WIDER Discussion Papers//World Institute for Development Economics (UNU-WIDER).

Djatikusumo, D. (2014). Determinants of SMEs adoption of information communication technology (ICT) and their impact on organizational performance in Indonesia. Canberra.

Electronic Commerce-ecommerce. (n.d.). Retrieved November 3, 2015, from http://www. investopedia.com

Janita, I., \& Chong, W. (2013). Barriers of B2B e-Business Adoption in Indonesian SMEs: A Literature Analysis. Procedia Computer Science, 571-578.

Kartiwi, M., \& Macgregor, R. (2013). Electronic Commerce Adoption Barriers in Small to Medium-Sized Enterprises (SMEs) in Developed and Developing Countries. Journal of Electronic Commerce in Organizations, 35-51.

Mazzarol, T. (2015). SMEs engagement with e-commerce, e-business and e-marketing. Small Enterprise Research, 22(1), 79-90. doi:10.1080/13215906.2015.1018400

Pavic, S., Koh, S., Simpson, M., \& Padmore, J. (2007). Could e-business create a competitive advantage in UK SMEs? Benchmarking: An International Journal Benchmarking, 320-351.

Promoting entrepreneurship and innovative SMEs in a global economy towards a more responsible and inclusive globalization; executive summary of the background reports; Istanbul, Turkey, 3-5 June 2004. (2004). Paris, France: OECD.

Tarute, A., \& Gatautis, R. (2014). ICT impact on SMEs performance. Procedia-Social and Behavioral Sciences, 110, 1218-1225. doi:10.1016/j.sbspro.2013.12.968 